\title{
Indigenous Use of Some Important Trans-Himalayan Medicinal Plants of Himachal Pradesh (North India)
}

\author{
Tsering Lamo*, Padma Gurmet, Phunstog Dolkar, Tashi Stobgais, Sonam Dawa, \\ Tsewang Dolma, Tsering Angdus, Stanzin Kunphel and Tsering Angmo
}

National Research Institute for Sowa-Rigpa (NRIS-Leh), (Central Council for Research in Ayurvedic Sciences, Ministry of AYUSH Govt. of India), Leh-194101, India

*Corresponding author

\begin{tabular}{|c|c|}
\hline & A B S T R A C T \\
\hline $\begin{array}{l}\text { Medicinal plants, } \\
\text { Himalayan, } \\
\text { Sowa-Rigpa, } \\
\text { Ayurveda }\end{array}$ & \multirow{3}{*}{$\begin{array}{l}\text { The survey on pictorial guide to commonly used medicinal plants of Sowa-rigpa and } \\
\text { Ayurveda was carried out and document } 50 \text { important medicinal plants used by the } \\
\text { traditional healer, out of } 50 \text { medicinal plants only } 11 \text { medicinal plants are selected for } \\
\text { present study. The raw material for these plants is the primary mode of health care for } \\
\text { most of the population and traditional doctors. Fresh leaves, fresh stem, root, bark, resin, } \\
\text { flower, seeds and sometimes the whole part of the plant are used for the preparation of folk } \\
\text { medicine. But the existing population of medicinal plants is declining at alarming rate due } \\
\text { destruction of habitat and unsustainable utilization lead to declining of number of } \\
\text { medicinal plant, therefore a preventive strategy is needed to maintain Himalayan ecology. } \\
\text { Present paper enables the readers to identify the use of various species for different kinds } \\
\text { of disease. }\end{array}$} \\
\hline Article Info & \\
\hline $\begin{array}{l}\text { Accepted: } \\
\text { 20 January } 2019 \\
\text { Available Online: } \\
\text { 10 February } 2019\end{array}$ & \\
\hline
\end{tabular}

\section{Introduction}

Plants have an immense economic and medicinal significance throughout the world. It is the basic requirement for human life like feeding, clothing, sheltering, nursing and hunting. The Indian Himalayan region is a mega hotspot of biological diversity (Myers et al., 2000; Boktapa and Sharma 2010). TransHimalayan regions are the treasure house of floristic wealth and Himalaya is known as a home for Ayurvedic and Sowa-Rigpa drugs (Gurmet et al., 1998). The major physiographic division of the state comprises three distinct regions the outer Himalaya, middle Himalaya and greater Himalaya. Himalaya, a hilly state with altitude ranging from 3500m -7000m above mean sea level (Sharma et al.,2012). Because of varied altitudinal and climatic condition, flora of Himalaya includes 8000 species of angiosperm, 44 species of gymnosperm, 600 species of pteridophyte and 1737 species of bryophyte (Polunin and Stainton 1987; Sharma et al., 2000).

The dominant family is Asteraceae followed by Poaceae and Fabaceae. Medicinal plants are used in Ayurveda, Sowa-rigpa and other system of medicine. The region is having 
several essential plants which are widely used in formulation of herbal drug in Ayurveda and Sowa-rigpa. The present study is based on medicinal plants of Himachal Pradesh it varied ecosystem it contains large number of plants which have rich medicinal and aromatic value. Medicinal plants gained importance recently not only as medicinal value but also as a ingredient for cosmetics industry (Sharma and Lal 2005; Sharma et al., 2012). There may be chances of extinction of medicinal plants due to change in climatic condition, lack of knowledge, over collection, unscientific exploration, uprooting for fuel, overgrazing and environmental degradation. All over the world demand for herbal based products are increasing day by day due to growing interest of people towards herbal medicine. Taking above points, it is therefore becomes imperative to conserve and cultivate those medicinal plants for present and future generation. And greater efforts should be given to document the outcome found during this period of time.

\section{In-situ conservation}

This is the best way of protection of biological and genetic diversity because here the wild species are preserved or protected in their own habitat. For example establishment of biosphere reserve, wild life sanctuaries, national parks, sacred grooves and many other protected area. Ultimately it will scrutinize the genetic loss.

\section{Ex-situ conservation}

Protection of species away from their natural habitat in a specific manner for long-term. Seed storage is considered as the best method of ex-situ conservation of endangered medicinal plant. It includes identification method and prioritization of taxa and another method of ex-situ conservation establishment of herbal garden, maintenance of medicinal plant nurseries and cultivation in farmer field.

\section{Study area}

The study area includes Marila, Rewalsar, Manikaran, Dharamshala and Jogindar nagar. Botanical name, Sowa-rigpa name, Botanical description, Sowa-rigpa uses and part use of 11 medicinal plants were provided with this paper. The Himachal state located between $30^{\circ} 22^{\prime} 40^{\prime \prime}-33^{\circ} 12^{\prime} 40^{\prime \prime} \mathrm{N}$ to $75^{\circ} 45^{\prime}, 55^{\prime \prime}-79^{\circ}$ $04^{\prime} 20^{\prime \prime}$. The region comes under various types of vegetation like tropical, temperate and alpine covering various kinds of flora of varying altitude diverse habitat, species, population, communities and ecosystem that possess difference with regards to various factors and features. Tropical vegetation includes plants with broadleaf, deciduous and evergreen. Subtropical vegetation is dominated by evergreen forest, ever coniferous forest and broadleaf deciduous. Temperate vegetation comprises of Cedrus sp, Pinus sp, Quercus sp, etc. Subalpine is dominated by Abies, Betula utitlis, Picea sp, etc. Apline vegetation mainly comprise herbaceous species, scattered patches of shrub such as Rhododendron sp, Juniper sp, Rosa macrophylla and Salix lindleyana are wide spread.

Himalaya with wide range of altitudinal gradient, deep mountain valley and area of high rainfall is a rich diversity of flora of endemism. The observation reveals that these medicinal plants are highly used to cure various different kinds of disease in Sowarigpa and Ayurveda. We documented the data of around 50 medicinal plants that are using in both system of medicine i.e. Ayurvedic system of medicine and Sowa-rigpa system of medicine. In this piece of writing only 11 important medicinal plants are selected which are highly used to cure various disease like blood disorder, diarrhoea, fever, ophthalmic disease, swelling of breast, constipation, amenorrhoea, indigestion, gastric, liver disease, genital warts, white discharge, etc. 


\section{Table.1 Observation}

\begin{tabular}{|c|c|c|c|c|c|c|}
\hline Botanical name & $\begin{array}{l}\text { Sowa- } \\
\text { rigpa } \\
\text { name }\end{array}$ & Family & Habitat & Botanical feature & Part use & Sowa-rigpa uses \\
\hline $\begin{array}{l}\text { Acorus calamus } \\
\text { Linn }\end{array}$ & $\begin{array}{l}\text { Shu-dag } \\
\text { nag-po }\end{array}$ & Araceae & $\begin{array}{l}\text { Habitats include } \\
\text { edges of small lakes, } \\
\text { ponds and rivers, } \\
\text { marshes, swamps, } \\
\text { and wetlands }\end{array}$ & $\begin{array}{l}\text { An herbaceous aromatic plant and } \\
\text { underground rhizome. Leaves are } \\
\text { ensiform and bright green. } \\
\text { Inflorescence spike-like spadix }\end{array}$ & Rhizome & $\begin{array}{l}\text { It cures appetite, diphtheria, chronic } \\
\text { wound, elephantiasis, arthritis, } \\
\text { poisoning and tag worms }\end{array}$ \\
\hline $\begin{array}{l}\text { Bergenia } \\
\text { stracheyi }\end{array}$ & $\begin{array}{l}\text { ga-dur- } \\
\text { kongli }\end{array}$ & Saxifragaceae & $\begin{array}{l}\text { Moist place, forests, } \\
\text { hills and high } \\
\text { mountains near } \\
\text { pastures }\end{array}$ & $\begin{array}{l}\text { A perennial herb, leaves are fleshy } \\
\text { and serrate margin. Inflorescence } \\
\text { cymose and flower pink in dropping } \\
\text { cluster. }\end{array}$ & $\begin{array}{l}\text { Rhizome, } \\
\text { leaves }\end{array}$ & $\begin{array}{l}\text { It cures common cold, diarrhoea, liver } \\
\text { and vessel fever }\end{array}$ \\
\hline $\begin{array}{l}\text { Camellia sinensis } \\
\text { (L.) Kuntze }\end{array}$ & jashing & Theaceae & $\begin{array}{l}\text { Tropical and } \\
\text { subtropical climates, } \\
\text { in areas with at least } \\
127 \mathrm{~cm} \text { ( } 50 \text { inches) of } \\
\text { rainfall a year. It } \\
\text { prefer a rich and } \\
\text { moist growing } \\
\text { location in full to part } \\
\text { sun, }\end{array}$ & $\begin{array}{l}\text { An erect solitary shrub, leaves } \\
\text { toothed, leathery, flower white with } \\
\text { ovate petal. Capsule round with } \\
\text { persistent calyx }\end{array}$ & Leaves & $\begin{array}{l}\text { It cure appetite, kappa and pitta } \\
\text { disorder }\end{array}$ \\
\hline $\begin{array}{l}\text { Curcuma longa } \\
\text { Linn. }\end{array}$ & yung-wa & Zingiberaceae & $\begin{array}{l}\text { It is a tropical plant, } \\
\text { and it grows in a } \\
\text { humid warm weather } \\
\text { with a lot of rainfall. }\end{array}$ & $\begin{array}{l}\text { A perennial herb, roots are fleshy and } \\
\text { tuberous. Leaves sheathing base, } \\
\text { undulate margin, parallel venation. } \\
\text { Flower grows between two sheathing } \\
\text { leaf base and inflorescence spike }\end{array}$ & Rhizome & $\begin{array}{l}\text { It cures toxicities, wound, } \\
\text { inflammation, haemorrhoids and nerves } \\
\text { disorder }\end{array}$ \\
\hline $\begin{array}{l}\text { Inula racemosa } \\
\text { Hook.f }\end{array}$ & Manu & Compositae & $\begin{array}{l}\text { Field and its } \\
\text { commercially } \\
\text { cultivated by the } \\
\text { locals. }\end{array}$ & $\begin{array}{l}\text { A perennial herb leaves narrowed to } \\
\text { winged, stalked, lanceolate, dentate. } \\
\text { Stem groved. infloresence spike. Ray } \\
\text { florets slender, woolly haired, disk } \\
\text { florets yellow. }\end{array}$ & Root & $\begin{array}{l}\text { It used to treat blood disorder and good } \\
\text { for acidic stomach }\end{array}$ \\
\hline $\begin{array}{l}\text { Plumbago } \\
\text { zeylanica Linn. }\end{array}$ & $\begin{array}{l}\text { Tse-rta- } \\
\text { ka(rGyar- } \\
\text { gyi-tse) }\end{array}$ & Plumbaginaceae & $\begin{array}{l}\text { Scrub jungles, } \\
\text { wastelands and } \\
\text { fallow lands. }\end{array}$ & $\begin{array}{l}\text { A tall perennial herb, stem nodular, } \\
\text { delicate with vertical striations, } \\
\text { leaves alternate, entire. Flower white, }\end{array}$ & Fruit & $\begin{array}{l}\text { It cures digestive heat, indigestion, } \\
\text { tumour, leprosy, haemorrhoids and } \\
\text { colon disorder. }\end{array}$ \\
\hline
\end{tabular}




\begin{tabular}{|c|c|c|c|c|c|c|}
\hline & & & & $\begin{array}{l}\text { bracteates, glandular born in spike } \\
\text { inflorescence. Fruit legumes, sticky. }\end{array}$ & & \\
\hline $\begin{array}{l}\text { Punica granatum } \\
\text { L. }\end{array}$ & Sin-du & Punicaceae & $\begin{array}{l}\text { Grown in dry areas } \\
\text { with either a } \\
\text { Mediterranean winter } \\
\text { rainfall climate or in } \\
\text { summer rainfall } \\
\text { climates. }\end{array}$ & $\begin{array}{l}\text { A large deciduous shrub leaves ovate, } \\
\text { opposite. Flowers scarlet large with } \\
\text { red petal. Fruit globular, crowned } \\
\text { calyx, thick leathery rind, flesh pink } \\
\text { juicy. Seed red or pink. }\end{array}$ & Fruit & $\begin{array}{l}\text { It helps to restore weak digestive heat } \\
\text { and cures indigestion, loss of appetite, } \\
\text { cold diseases and disorder of rlung. }\end{array}$ \\
\hline Rheum australe & Chhu-rTsa & Polygonaceae & $\begin{array}{l}\text { Grassland, forest, open } \\
\text { slopes, rocky and } \\
\text { moist place. }\end{array}$ & $\begin{array}{l}\text { A perennial herb leaves rounded to } \\
\text { broadly ovate, reddish brown at } \\
\text { maturity. Rootstock stout. }\end{array}$ & Roots & $\begin{array}{l}\text { It cures infection, indigestion, chronic } \\
\text { and fresh wounds. }\end{array}$ \\
\hline $\begin{array}{l}\text { Terminalia } \\
\text { chebula }\end{array}$ & Aa-ra-ru & Combretaceae & $\begin{array}{l}\text { Warmer region of } \\
\text { foothills, among } \\
\text { shrubberies and } \\
\text { roadsides. }\end{array}$ & $\begin{array}{l}\text { A tall deciduous tree with thick bark, } \\
\text { longitudinal furrows. Wood hard, } \\
\text { bulky. Leaves ovate, alternate, and } \\
\text { entire. Inflorescence spike and } \\
\text { flowers dull yellowish. Fruit ovoid, 5- } \\
\text { ribbed. }\end{array}$ & Fruits & $\begin{array}{l}\text { It is an excellent blood purifier and } \\
\text { good health tonic. }\end{array}$ \\
\hline $\begin{array}{l}\text { Terminalia } \\
\text { bellirica }\end{array}$ & ba-raru & Combretaceae & $\begin{array}{l}\text { Scattered forests, } \\
\text { sunny mountain } \\
\text { slopes, one of the } \\
\text { upper layer trees of } \\
\text { stream valleys and } \\
\text { lower seasonal rain } \\
\text { forests at elevations of } \\
500-1,400 \text { metres. }\end{array}$ & $\begin{array}{l}\text { A tall deciduous tree dark brown. } \\
\text { Leaves thick, alternate, clustered } \\
\text { towards end of the branches. } \\
\text { Inflorescence spadix. Flower solitary. } \\
\text { Fruit globular. Seed coat hard, taste } \\
\text { like walnut. }\end{array}$ & Fruits & $\begin{array}{l}\text { It cures bile disorder, dries excess } \\
\text { lymph accumulation and skin diseases. }\end{array}$ \\
\hline $\begin{array}{l}\text { Tinospora } \\
\text { cordifolia }\end{array}$ & sle-tres & Menispermaceae & $\begin{array}{l}\text { It prefers wide range } \\
\text { of soil, acid to alkaline } \\
\text { and it needs moderate } \\
\text { level of soil moisture. } \\
\text { Found throughout } \\
\text { tropical India. }\end{array}$ & $\begin{array}{l}\text { A deciduous woody climber. Stem } \\
\text { succulent, twining branches, tentacles } \\
\text { hanging down, bark corky. Leaves } \\
\text { long petiolate, alternate, cordate, } \\
\text { entire. Flowers unisexual. } \\
\text { Inflorescence raceme. Fruit drupe. }\end{array}$ & Stem, branch & $\begin{array}{l}\text { It balances three principal energies } \\
\text { (rlung, mkhis pa and badkan), cures } \\
\text { infectious fever, pain, arthritis, gout and } \\
\text { chronic fever. }\end{array}$ \\
\hline
\end{tabular}


Picture Plates-1

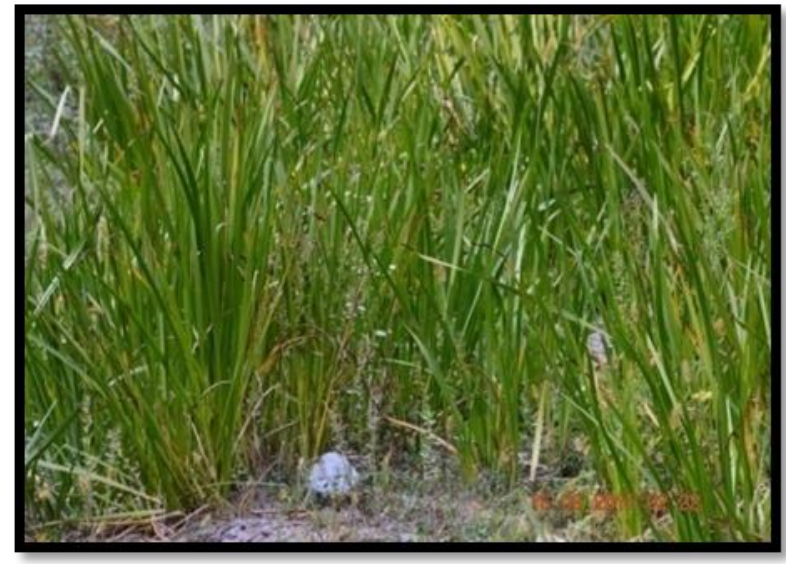

Acorus calamus

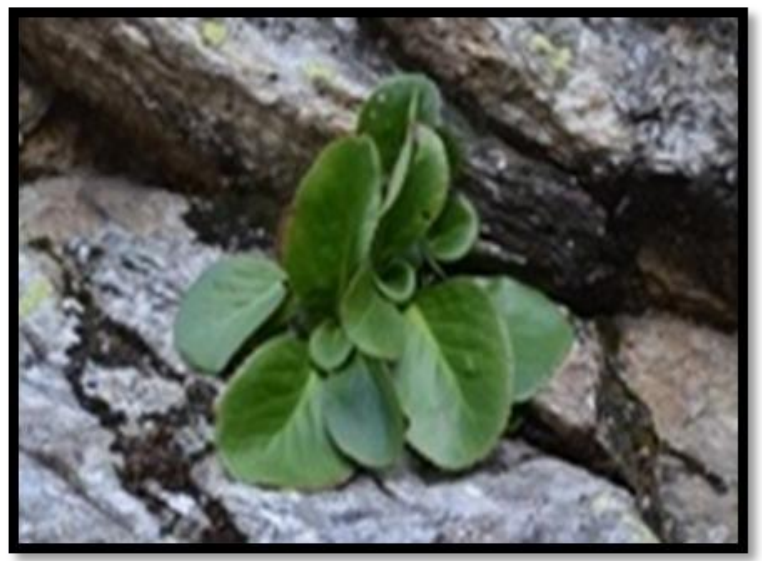

Bergenia

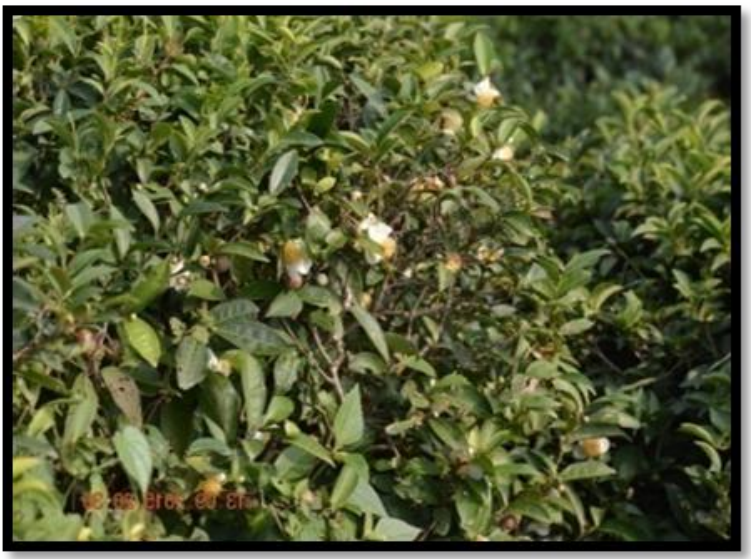

Camellia sinensis

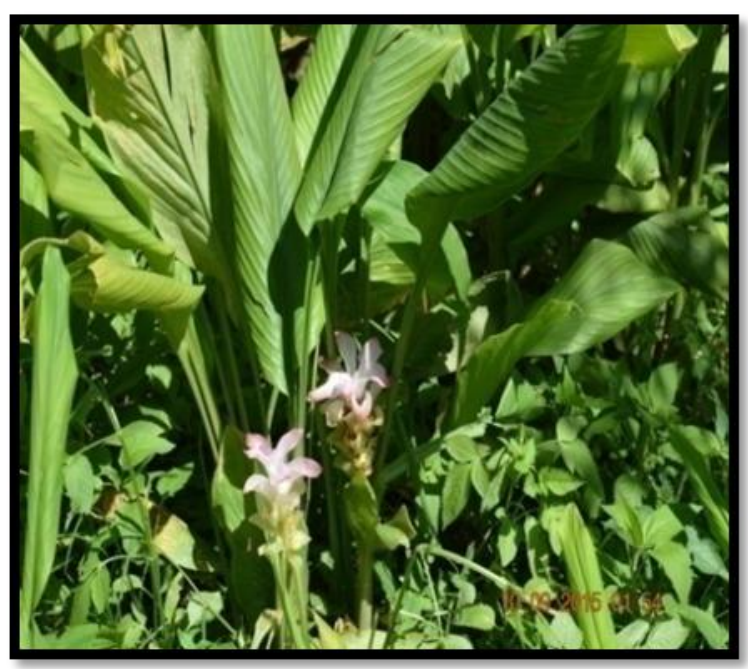

Curcuma longa

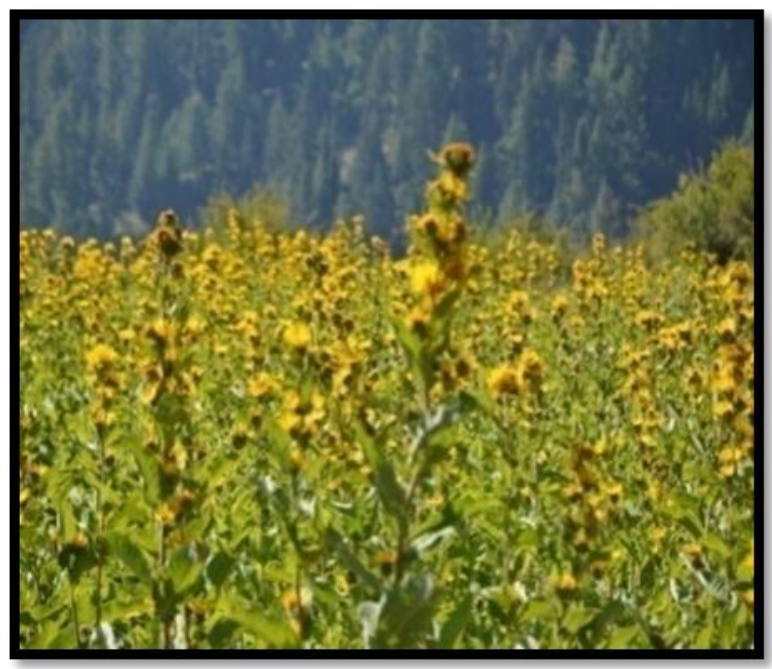

Inula racemosa 


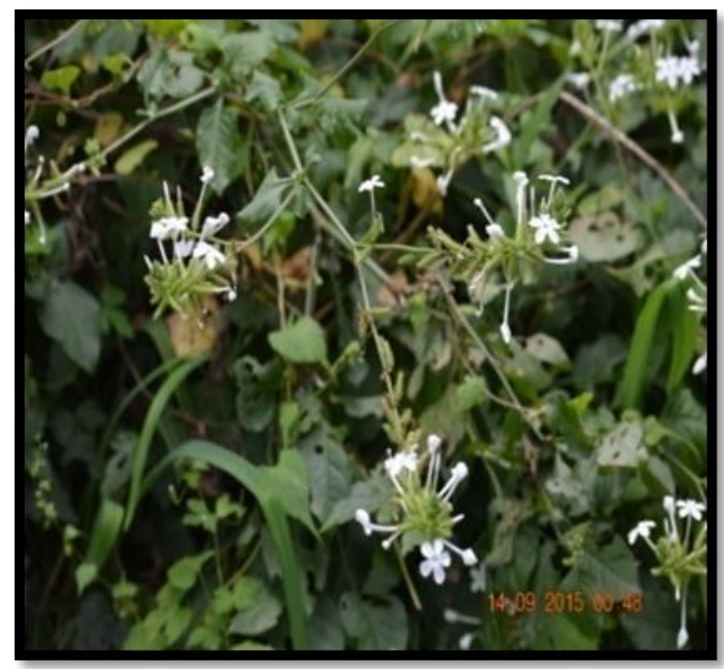

Plumbago zeylanica

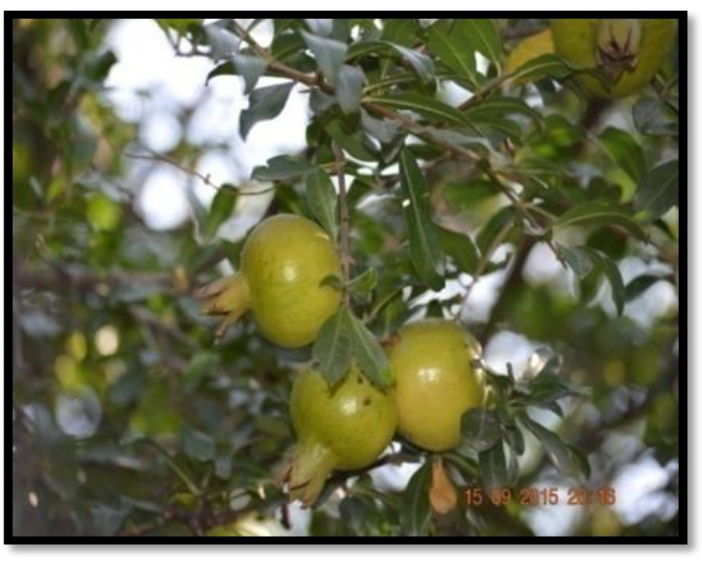

Punica granatum

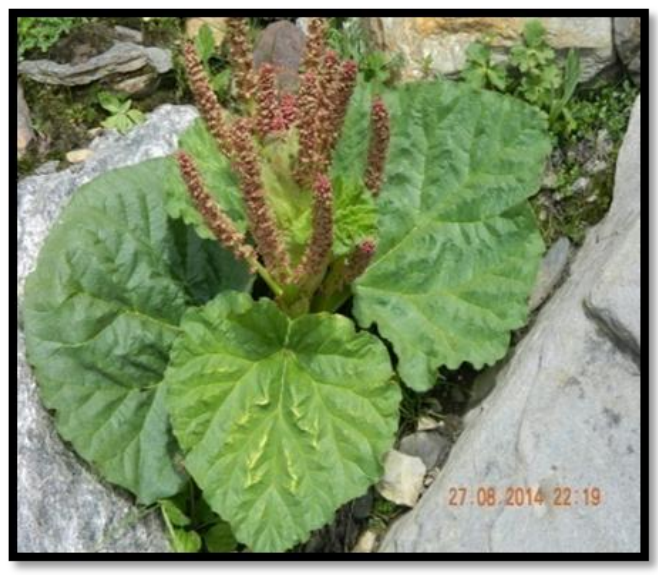

Rheum australe

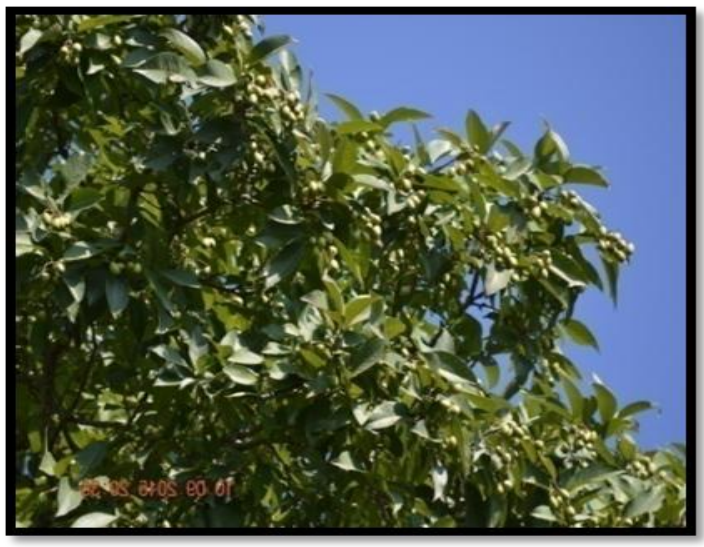

Terminalia chebula 


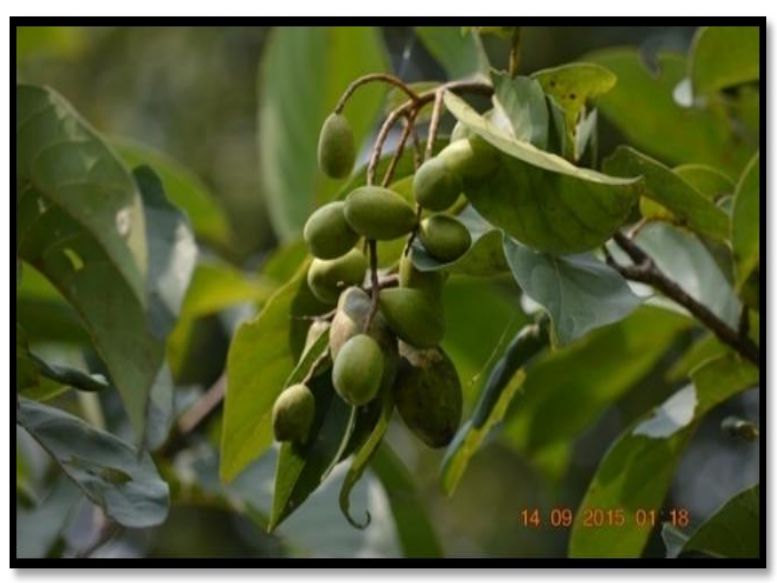

Terminalia bellerica

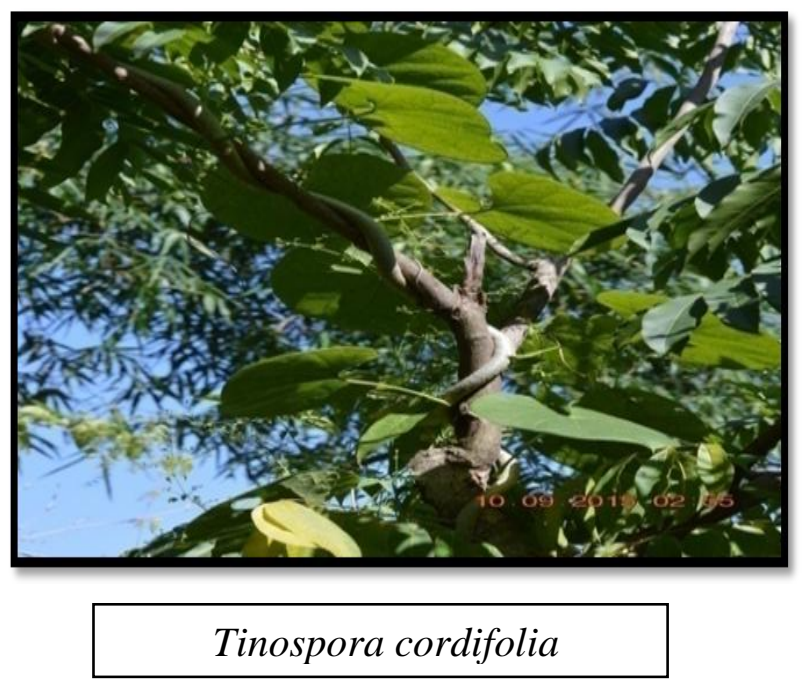

commercially viable are crucial to ease the pressure on natural habitat. Some of methods for conservation are:-

- Effective in situ and ex situ conservation.

- Organized and rational collection.

- Identification and commercially viable medicinal plants

- Documentation of indigenous use and traditional practise

- Development of agro techniques and propagation protocol.

- Heavy grazing and destruction should be checked.

All of this action requires collaboration of state and central government along with NGO's, researchers, farmers to work together. The authors are thankful to officers and staff members of National Research Institute for Sowa-rigpa, Leh for their help during the study and Central Council for Research in Ayurvedic Sciences and Ministry of AYUSH for funding the study.

\section{References}

Boktapa, N.R. and Sharma, A.K. 2010. Wild medicinal plants used by local communities of Manali, Himachal Pradesh, India. Ethnobotanical 
Leaflets 14: 259-267.

Gurmet, P., Chaurasiya, O.P., Singh, B. and Singh, D.V. 1998. Some traditional medicinal plants of Khardungla and Changla (Ladakh) used in Amchi medicine. Bulletin of Medico-EthnoBotanical Research 19(3-4): 93-101

Myers, N., Muttermeier, R.A., Muttermeier, C.A., da Fonseca, A.B.G. and Kent, J. 2000. Biodiversity hotspots for conservation priorities. International Journal of Science Nature 403:853861.

Polunin, O. and Stainton, A. Concise flowers of the Himalaya published by Oxford University Press (1987).

Sharma, P. C., Yelne, M. B., Dennis, T. J., Joshi, A., Prabhune, Y.S., Khade, K., Sharma, D.P. and Singh, P.B. 2000. Database on medicinal plants used in
Ayurveda Volume 1, 2 and 3 Central Council for Research in Ayurveda and Siddha (India) Govt. of India.

Sharma, P.K. and Lal, B. 2005. Ethnobotanical notes on some medicinal and aromatic plants of Himachal Pradesh. Indian Journal of Traditional Knowledge 3 (4): 424-428.

Sharma, S.K. 2012. Need for conservation and propagation of medicinal plants of Himachal Pradesh, India. Indian Journal of Plant Sciences 1(2-3): 217220.

Sharma, V., Bhardwaj, U. and Sharma, S. 2012. Medicinal Plants: Need for Sustainable Exploitation (With Special reference to Himachal Pradesh). Journal of Pharmacy Research 5(8): 4313-4317.

\section{How to cite this article:}

Tsering Lamo, Padma Gurmet, Phunstog Dolkar, Tashi Stobgais, Sonam Dawa, Tsewang Dolma, Tsering Angdus, Stanzin Kunphel and Tsering Angmo. 2019. Indigenous Use of Some Important Trans-Himalayan Medicinal Plants of Himachal Pradesh (North India). Int.J.Curr.Microbiol.App.Sci. 8(02): 2682-2689. doi: https://doi.org/10.20546/ijcmas.2019.802.313 